Journal Home Page:

http://perlinguam.journals.ac.za

\section{Per Linguam}

A Journal for Language Learning Tydskrif vir Taalaanleer

\title{
FOUNDATION PHASE STUDENT TEACHERS' VIEWS TOWARDS LEARNING ISIXHOSA IN THE B.ED. TEACHER EDUCATION PROGRAMME
}

\author{
Nokhanyo Nomakhwezi Mayaba \\ University of South Africa
}

Teacher education programmes in South Africa are mandated by the Minimum Requirements for Teacher Education Qualifications (MRTEQ) framework to ensure that students can converse competently in one of the indigenous languages. Therefore, an opportunity to learn such a local indigenous language should be given. As part of the BEd recurriculation process, students were involved in the learning and development of an isiXhosa module. I conducted a qualitative inquiry with a group of fourth-year Foundation Phase students $(n=15)$ who volunteered to participate in this study. The aim of this study was to explore students' views on learning isiXhosa in their BEd (Foundation Phase) programme. I used a draw and write/talk technique followed by semi-structured group interview discussions as data generation methods. Themes that emerged from the data revealed the following: 1) the value of learning isiXhosa for communication purposes in the classroom, 2) the recognition of isiXhosa as a resource for teaching and learning, 3) isiXhosa as an enabler to function in a multilingual society, and 4) a need to design a module that enhances the acquisition of isiXhosa. These findings suggest that teacher education programmes need to recognise the value of indigenous languages in advancing the pedagogy of teaching in multilingual classrooms. Understanding student teachers' views on learning an indigenous language will contribute to knowledge on the purpose of learning isiXhosa and how the current isiXhosa module is capacitating them to teach in multilingual contexts.

\section{Keywords}

Teacher education programmes, isiXhosa conversational module, foundation phase, multilingual context, indigenous language

\section{INTRODUCTION}

Learning to converse competently in an indigenous language is one of the knowledge fields advocated by the Minimum Requirements for Teacher Education Qualifications (MRTEQ) (Department of Education, 2011). This suggests that students whose first language is English or Afrikaans should have an opportunity to learn it on a conversational level in their teacher education programme. Although the purpose of learning an indigenous language is not explicitly stated in the MRTEQ, the idea seems to draw from the recognition that most classrooms in South Africa are multilingual (Naicker \& Balfour, 2009; Pluddemann, Mati \& Mahlalela-Tusi, 1998) and therefore teachers need to be prepared to teach in linguistically diverse settings. Moreover, the types of learning such as the situational and fundamental learning as described in the MRTEQ (Department of Education, 2011) emphasise the importance of understanding the environment 
and the contexts in which student teachers are prepared to teach. This suggests that knowledge of an indigenous language could enable the student teachers to interact in a culturally diverse context.

Research that reports on the multilingual nature of classrooms in South Africa after the demise of apartheid highlights the difficulties teachers face in these classrooms, especially when the teachers and learners do not share a common language (Evans \& Cleghorn, 2010; Pluddemann et al., 1998; Van der Walt, 2009). In foundation phase classrooms (Grade R-3), communication is very important and communicative difficulties are more prevalent (Black, 2004) because it is difficult for learners to acquire a language of learning and teaching which is different from their own linguistic or dialectic repertoires (Bourne, 2001; Evans \& Cleghorn, 2010), while they are not even proficient in their home languages (Bloch, 2002). Preparing a teacher for such classrooms requires a teacher education programme that takes into account the degree to which offering only one isiXhosa module will capacitate teachers to acquire isiXhosa and be able to use it for classroom purposes.

In the Faculty of Education at Nelson Mandela Metropolitan University where I taught, all fourth-year students who were English or Afrikaans home language speakers, who had never learnt isiXhosa in schools or had basic knowledge of the language, were required to register for an isiXhosa conversational module for a year. The purpose of this module was to build their communication skills in isiXhosa. It was offered once a week for 70 minutes and carried six credits. However, students had hinted during informal conversations that, during their teaching practice period, they recognised that most learners in their classes were isiXhosa speakers and therefore felt that their communicative needs went beyond learning isiXhosa on a conversational level. As a lecturer who supported and mentored foundation phase student teachers during their teaching practice, I also noted that they would sometimes code-switch to Afrikaans but found it difficult to code-switch to isiXhosa, in spite of them learning isiXhosa while doing teaching practice. I first wondered if the content of the isiXhosa module they were learning was equipping them with skills to use isiXhosa in their foundation phase multilingual classrooms. Moreover, I wondered if these students saw a need to learn isiXhosa in the first place, as Sosibo's (2012) study highlighted that the students and lecturers in her study did not prioritise the fundamental learning in the MRTEQ as contributing to the future of teachers.

Dowling (2010) has reported on the teaching strategies that she is using in her context, but they are mostly to assist the students to immerse in the social context of isiXhosa speakers. Kese's (2012) study on teaching isiXhosa to non-indigenous speakers of the language revealed ways in which the communicative competences of these students could be improved. I was concerned about the learning experiences of students during the course of this module and what their views were about this module, in the light of them as future teachers in this country. This is important to know so that I understand how this module has or has not equipped them in order to make recommendations to change it. Understanding student teachers' views on learning an indigenous language will contribute to knowledge as they are also playing a role of being co-constructors of knowledge in this project.

This article aims to determine and describe foundation phase student teachers' views on learning isiXhosa as a conversational language as part of the BEd teacher programme. My research 
questions are: What do foundation phase student teachers think is the purpose of learning isiXhosa in a BEd (Foundation phase) programme? How has an isiXhosa module capacitated students to effect teaching and learning in their multilingual classrooms? Through this article I hope to raise a debate on how an indigenous language can be positioned in teacher education programmes in order to meet the communicative demands of multilingual classrooms and to highlight students' views on the learning of indigenous languages. In the following sections I begin by describing the theoretical framework that underpins this study. Afterwards, I provide details of the methodology; discuss the findings and reflect on their significance for teacher preparation programmes in the context of multilingual classrooms.

\section{THEORETICAL FRAMEWORK}

I view teaching and learning through the lens of social constructivism (Vygotsky, 1978). This theory advocates that learning takes place when learners engage actively in the process of learning. Learners become the constructors of knowledge, having been scaffolded and guided through collaborative learning activities (Mercer, 1995; Vygotsky, 1978). In this process, teachers play a central role as they ought to create a conducive learning environment (Mercer, 1995). Similarly, most researchers who investigate the classroom discourse argue that the quality of knowledge that is constructed by both the teachers and learners relies on the quality of communication that takes place in the classroom (Bourne, 2001; Nomlomo, 2010; Pontefract \& Hardman, 2005). When both the teachers and learners are experiencing communication barriers, learning is least likely to take place; hence, most classroom practices are reported to be dominated by teacher talk and silence on the part of the learners (Black, 2004; Pontefract \& Hardman, 2005). When learners and teachers do not interact in class, learning might be affected (Evans \& Cleghorn, 2010; Nomlomo, 2010). This situation is exacerbated when teachers do not take into account that, when learners come to school they bring with them a variety of languages and codes (Bourne, 2001; Garcia, 2009), therefore teaching in multilingual classrooms suggest that teachers should be able to effect learning by using these 'various languages as resources' (Setati \& Adler, 2001: 246). Learners need to talk to learn, and such talking to learn is a function of fluency and ease in the language of communication (Mercer, 1995).

Blommaert, Collins and Slembrouck (2005: 198) suggest that using a language to communicate is determined by the requirements of language goals in that particular environment. This implies that positioning a student teacher in a foundation phase multilingual context will be more effective if that particular teacher is able to use language as required in this phase. Given that oral communication is vital in the foundation phase (Department of Education, 2011) and that learners are still learning the language of learning and teaching, this means teachers need to be in a position to use their learners' home languages (including isiXhosa) so as to effect learning. However, when teachers are not aware that the level of first and additional language competencies that learners possess, which enable them to make meaning of the language through which they are taught, is important, there are likely to be learning difficulties. This means that the type and quality of language input learners receive from their teachers should cater for their own language abilities. This view supports Krashen's (1982) theory of second language acquisition, which highlights the distinction between language learning and language acquisition. Learners in the foundation phase obviously have not yet acquired the additional language through which they are taught, and given Cummin's (1979) conceptual distinction between a conversational and an 
academic language, it will take a number of years before these learners are in a position to use the language of learning and teaching; hence, teachers' knowledge of an indigenous language would be effective in these classrooms.

Pluddemann et al. (1998) report on how teachers in their study felt that teaching learners whose mother tongue was not English was an added burden to them, as they had limited linguistic abilities to code-switch to indigenous languages. Extending this observation, Probyn (2009:123) comments that, in teacher training programmes, the multilingual realities of the classrooms have been viewed from a deficit lens, meaning that the different languages that learners bring to the learning situation have been viewed as a problem (O'Connor \& Geiger, 2009). Although these views have merit in a context where teachers' linguistic repertoires have not been extended beyond their home languages, the reality of classrooms challenges how teachers are prepared to teach in diverse settings. In most cases, teachers find themselves 'in between' following the schools' language policies, which construct classrooms as monolingual, and meeting the multilingual practical demands of their classroom discourses (Bourne, 2001; Mitchell, 2012; Probyn, 2009). In the context of this paper, understanding student teachers' views and recognising them as contributing to knowledge on learning an indigenous language seemed to resonate with the demands of a multilingual classroom discourse. By participating in this study, student teachers could reflect and talk about how the use of an indigenous language plays a role in teaching and learning when teaching in multilingual contexts. I argue that, in preparing teachers to teach in multilingual classrooms, their communicative potential should be enhanced to be effective in these classrooms. In other words, when they engage with the learners in a classroom situation, they need to be aware that language plays a significant role and therefore, if teachers cannot communicate in the language of the learners, especially in the foundation phase, communication barriers are more likely to occur.

Research on classroom strategies in South Africa point to the use of code-switching as an effective way of eliciting talk and communication in the classroom (Setati \& Adler, 2001) and the use of hybrid practices as valid approaches to deal with a multilingual context (Makoe \& McKinney, 2009). If that is the case, classroom interaction and learning requires a teacher who can switch between languages. Interestingly, in a study conducted by Madiba (2012), a strategy called translanguaging enabled an effective learning environment, as participants were able to use various languages as per the demands of their conversation discourse. These findings support Garcia's (2009) argument that most language policies are framed within a monolingual classroom reality, which is 'not' a reality at all. Understanding student teachers' views on learning an indigenous language, who were teaching in foundation phase multilingual contexts during the time of their teaching practice, will contribute to knowledge on the purpose of learning isiXhosa and how the current isiXhosa module is capacitating them to teach in such contexts.

\section{METHODOLOGY}

This is a qualitative study which is underpinned by an interpretive paradigm (Creswell, 2009). The participants who volunteered to be part of this study were 15 foundation phase student teachers who were registered for a BEd (Foundation Phase) programme at Nelson Mandela Metropolitan University. They were all female students between the ages of 21-23 whose home 
languages were either English or Afrikaans. In reporting the data, participants were labelled as Participant 1-15.

I adopted qualitative methods such as a draw and write/talk technique (Theron, Mitchell, Smith \& Stuart, 2011) and semi-structured group interviews (Creswell, 2009) as data generation methods. I used drawings because research with adults indicates that they are useful as a tool to explore individuals' thoughts and insights on a particular issue (De Lange, Olivier, Geldenhuys \& Mitchell, 2012). The format of the drawing approach is explained by Mair and Kierans (2007:122) as follows: 'First participants respond to a researcher's enquiry with a drawing. Second participants are then asked to elaborate on their completed drawing through written answers to further describe and clarify the content of the picture and then provide a commentary around which the researcher can build their analysis'. The prompt that was given to the participants was: 'Draw and explain/write what you think is the purpose of learning isiXhosa in your BEd programme'. Their drawings and accompanying articulations informed the interview discussion. The main question for the interview was: 'Given what you have indicated as the purpose for learning isiXhosa, how has the isiXhosa module capacitated you to teach in foundation phase multilingual classrooms?' The purpose of the interviews was to allow participants to articulate their views on learning isiXhosa in their teacher education programme and how their module has capacitated them to teach in foundation phase multilingual settings.

In analysing the drawings and accompanying explanations, the focus was not on drawings but the meanings the participants made of their drawings, a process called shared analysis (De Lange et al., 2012). Interview data were recorded and transcribed and then triangulated with the data from the draw and write technique. Themes from the data were then analysed (Braun \& Clarke, 2006) and discussed. These themes were sent to the participants for comments in a process of member checking (Creswell, 2009). The trustworthiness of the research was ensured by means of triangulation of data collection methods, use of verbatim quotes from the participants' explanations of their drawings and interview data (Creswell, 2009). I interpreted these data in terms of how they answered my research questions.

In order to meet the ethical requirements (Swartz, 2011), the students signed consent forms stating that they had been informed about the purpose and the process of the study, that they knew that confidentiality would be ensured, and that they understood that their participation was voluntary and that they were free to withdraw from the study at any time. They were made aware that I might make use of their data in publications related to my research. The study was granted ethical clearance (H13-EDU-ITE-037) by the university's Research Ethics Committee, which requires evidence of strict adherence to ethical measures.

\section{RESULTS AND DISCUSSION}

Themes that emerged from data analysis revealed that student teachers viewed learning isiXhosa as serving different purposes in their lives. However, they were critical of how the isiXhosa conversational module had capacitated them to use it in multilingual foundation phase classrooms. In addition, they provided suggestions on how this module could be improved. Firstly, they acknowledged the value of learning isiXhosa for communication purposes in the 
classroom; secondly, they recognised isiXhosa as a resource for teaching and learning; thirdly, they viewed isiXhosa as an enabler to function in a multilingual society; and finally, they critiqued the module and then highlighted ways in which their competencies in isiXhosa could be developed.

\section{STUDENTS' VIEWS ON THE PURPOSE OF LEARNING ISIXHOSA IN THEIR B.ED. PROGRAMME}

\section{The value of learning isiXhosa for communication purposes in the classroom}

In any classroom, language plays a significant role as a means of communication (Bourne, 2001; Nomlomo, 2010; Pontefract \& Hardman, 2005). In a multilingual foundation phase classroom where learners are not proficient in either their home language or language of learning and teaching, it is clearly important for the teacher to be able to interact with all learners. In explaining the purpose of learning isiXhosa, Participant 12 thought that the purpose of conversational Xhosa is to ensure that I as a teacher am able to converse with all learners in my class. Majority of my learners this year was or rather is Xhosa first language learners. It will brighten a child's day to know that the teacher can understand what they are trying to say especially that the majority of learners are isiXhosa home language learners'.

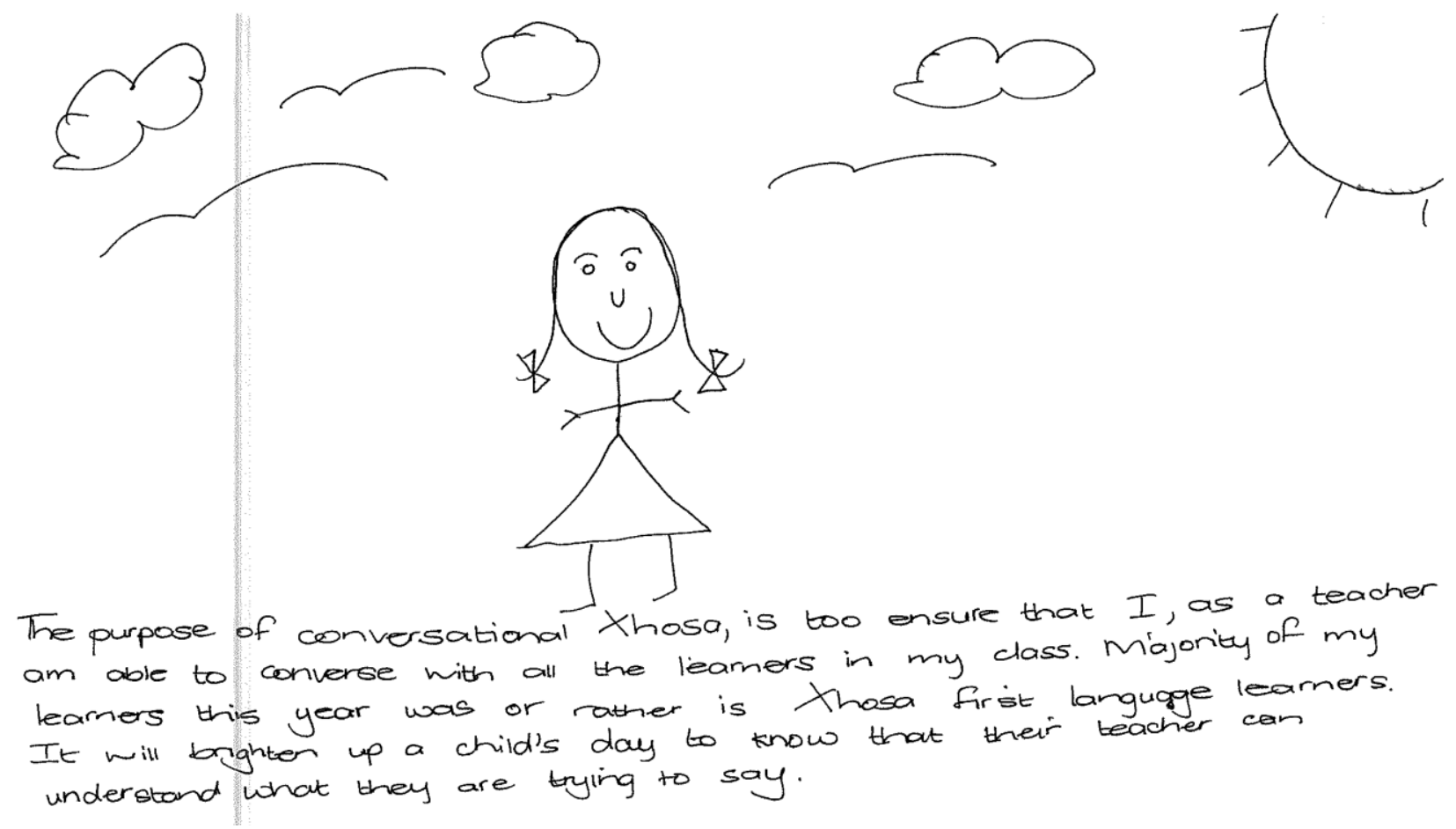

\section{Figure 1: Drawing by Participant 12}

This view was supported by Participant 8 who said learning isiXhosa will enable me to communicate effectively and learners will feel that a classroom is a safe environment to express themselves-hence learning isiXhosa enables a teacher to build better relationships with their 
Xhosa learners'. Participant 10 added that 'learning IsiXhosa allows us to cross the language barriers and also give more insight into how our Xhosa learners think, speak and talk'.

What was apparent in these data was the need for the student teachers to be able to communicate with the learners in the classroom in order to understand what the learners are also trying to communicate. What these data confirm is that South African classrooms are multicultural and multilingual and that some learners do not have access to the language of the teacher (Naicker \& Balfour, 2009). In situations where teachers cannot use basic interpersonal communication skills (Cummins, 1979) in the learners' language, communication barriers are eminent; hence, data revealed the value of learning isiXhosa for communication purposes in the classroom.

It seemed as if Participant 5 recognised how important communication is in building positive relationships (Pienaar \& Raymond, 2013) in class, as she said 'the purpose of the module is to help us communicate with learners who speak Xhosa. When you don't understand someone you feel sad and confused'. She further recognised that classrooms are multilingual (Naicker \& Balfour, 2009) and therefore '[y] ou cannot assume that everybody knows Afr/Eng'.

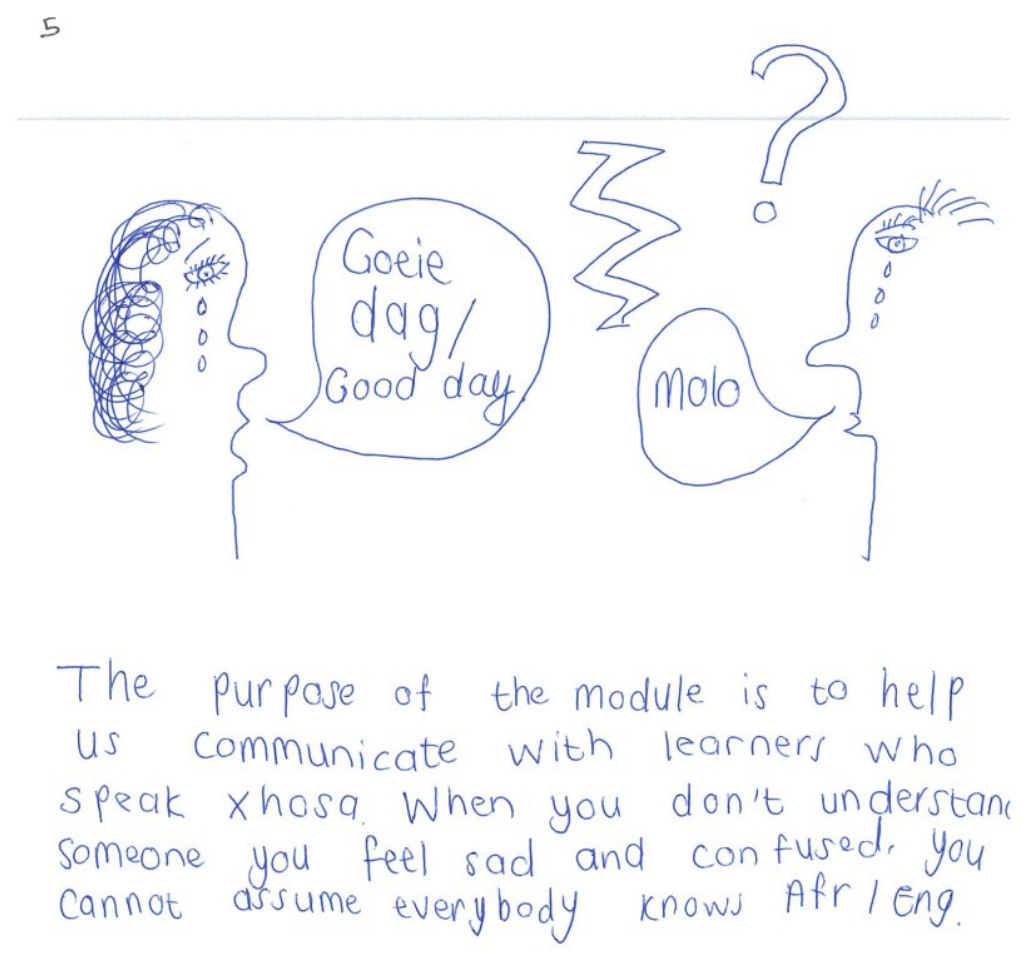

Figure 2: Drawing by Participant 5

The purpose of learning isiXhosa for communication in classrooms was further supported by Participant 3, who said that 'the ability to communicate on a very basic level will show that you are willing to try and use some Xhosa to talk to them [learners]' and that the 'purpose would be to be able to converse in isiXhosa or to know some words or phrases that will help your Xhosa learners take you seriously or make them feel important'. These data contradict the assertion that multilingual realities of classrooms have been viewed as a problem (O'Connor \& Geiger, 2009), 
as student teachers recognised the significance of conversing in isiXhosa. It therefore appears that the quality of knowledge that can be constructed in a classroom is highly dependent on the quality of communication that takes place (Nomlomo, 2010). Hence, without the knowledge of the different languages that learners bring into a classroom, which include the indigenous languages, teaching and learning is more likely to be negatively affected.

\section{IsiXhosa as a resource for teaching and learning}

In classroom practices, language serves a specific purpose as it is either used for academic or social purposes. Participant 1 explained her drawing orally by indicating that 'learning isiXhosa will help me to give instructions to all learners in their mother tongue'. Giving instructions is part of teaching and learning (Pienaar \& Raymond, 2013); however, when those instructions are not understood by the learners, learning will not take place. These data confirm research which asserts that in classrooms teachers use code-switching (Setati \& Adler, 2001) as a strategy to explain the key concepts when teachers and learners share a common language which is different from the language of learning and teaching. In this study, Participant 1 points out clearly that learning isiXhosa will enable her to give instructions. It appears that the expectation is that this module should enable her to be able to do so. This suggests that students need to acquire the language (Krashen, 1982) because giving instructions requires a level of proficiency in that particular language.

Participant 2 asserted that 'it is nice to incorporate [Xhosa] when doing lessons' and 'to help a child who can't speak English' (referring to Participant 7). When I asked her to explain this assertion she said that she wanted to be able to assist learners when they are doing tasks in class by speaking isiXhosa. This suggests that teachers need to be able to scaffold (Vygotsky, 1978) learning by assisting learners to be able to engage with tasks until they are able to do that independent of the teacher. In order to help a child who is proficient in Xhosa, a teacher needs a certain level of proficiency as well. Participant 2 added that it is important to be able to speak to the learners who may not be able to express themselves in English'. In any learning situation, a language plays a central role as a resource for teaching and learning (Black, 2004), and speaking involves turn taking (Nomlomo, 2010). For these teachers to be able to speak to the learners, they need to interact through a language and to be able to understand what they are conversing about. 


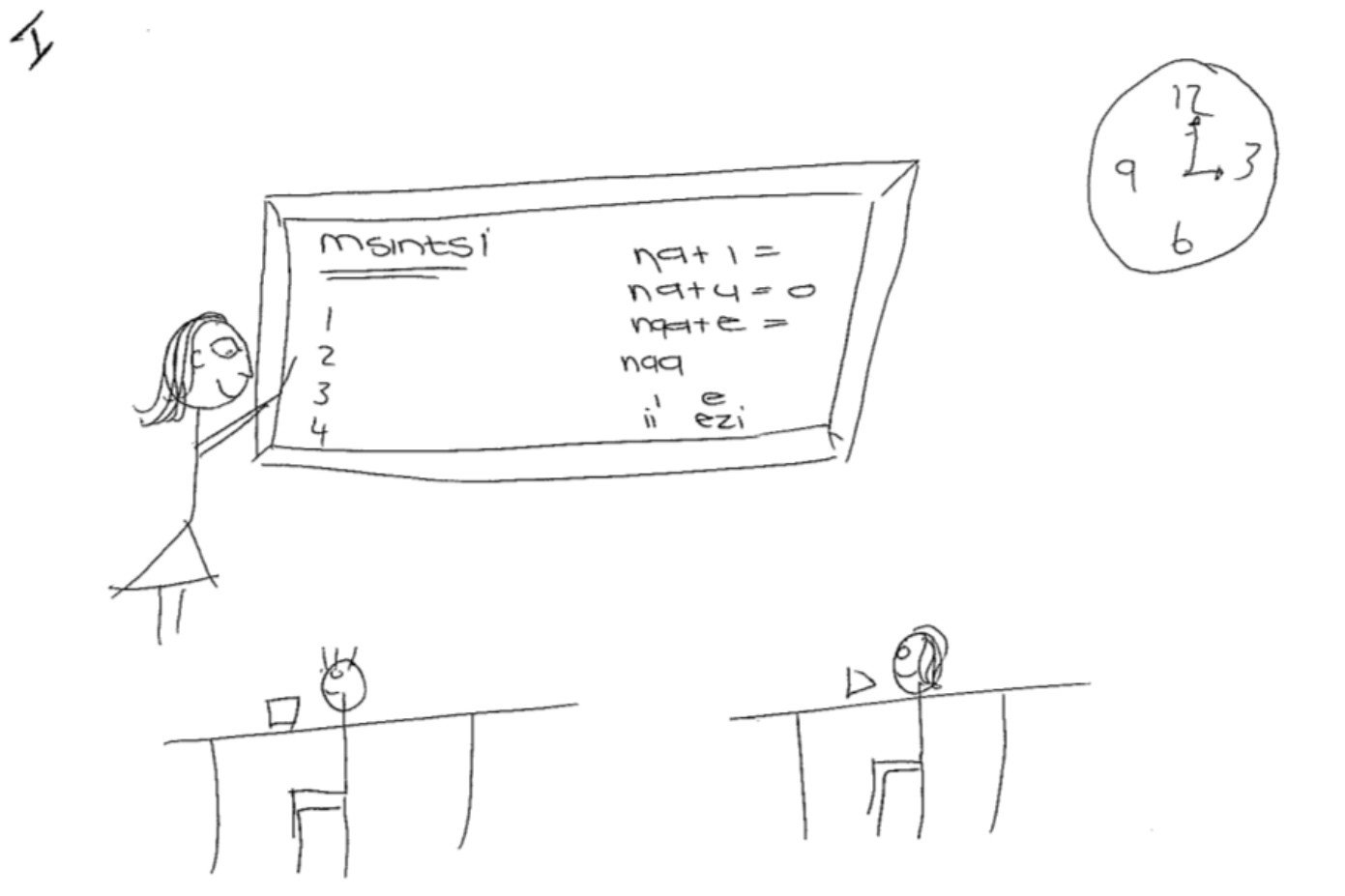

\section{Figure 3: Drawing by Participant 2}

IsiXhosa as an enabler to function in a multilingual society

Teachers do not exist in isolation from the bigger society, as they are members of a community of practice. This involves the parents of the learners, the other staff personnel and people outside their schooling environment. In explaining her drawing, Participant 14 said 'In this drawing I have drawn a customer in a restaurant which represents an activity in our everyday lives. I view the purpose of this module to be to enable its students to converse in isiXhosa on a daily basis and in everyday situations e.g. when in hospital, at school, in the shop etc.' 


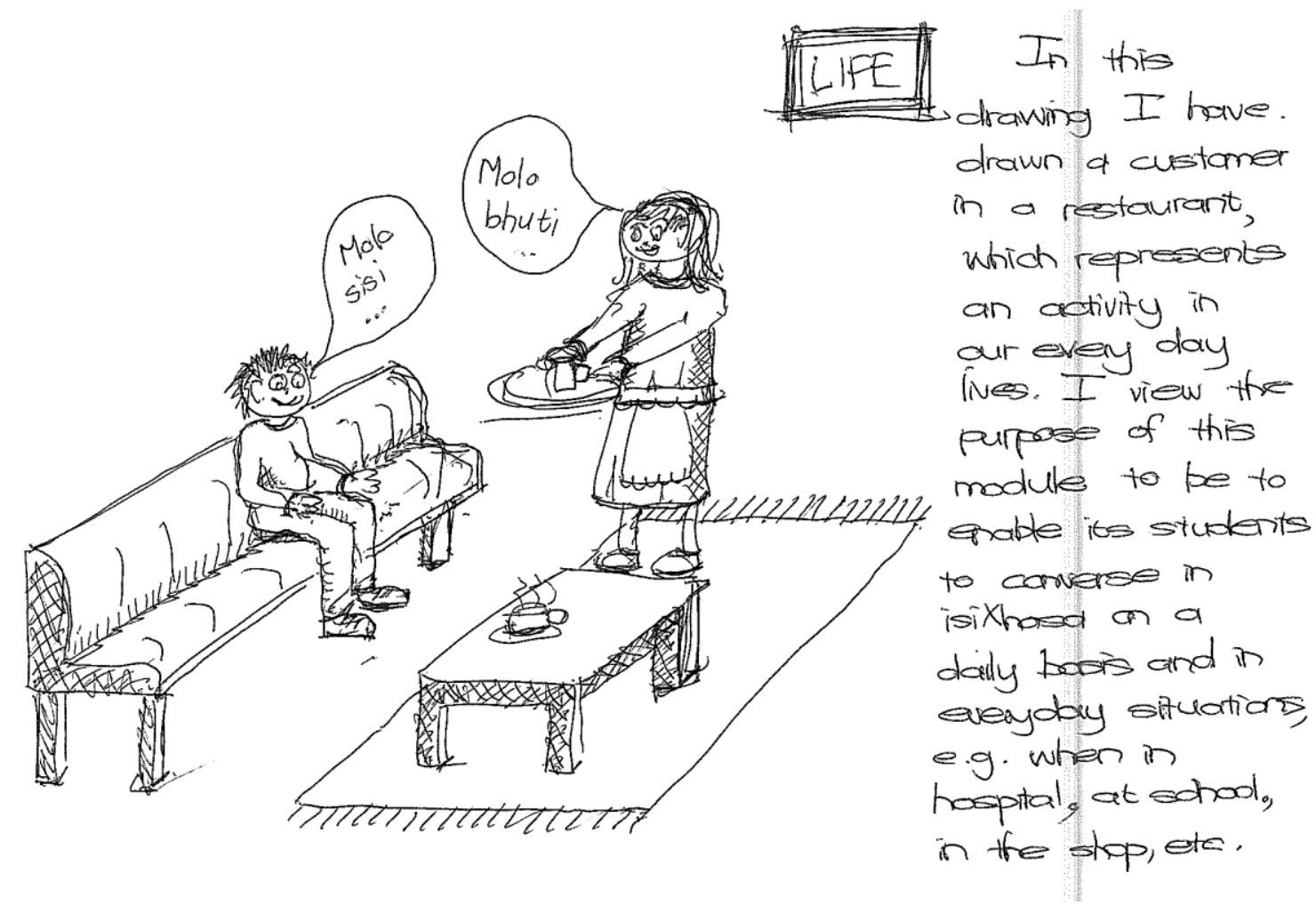

Figure 4: Drawing by Participant 14

Participant 1 said that '[l]earning isiXhosa allows for a better integration between cultures as well as open communication'. Participant 4 said that 'as a diversified citizen of South Africa we can learn to communicate at a respectful manner and achieve a greater sense of unity and respect amongst us all'. 'I will be able to greet people young and old from all walks of life' (Participant 15). Having recognised their role in multilingual societies, students also realised that there are varieties of isiXhosa. Participant 6 said that 'staff personnel in the school and other people speak a different Xhosa than the one taught in class'. This raises a point on the learning of the language and the significance of exposing student teachers to both the standard and colloquial language, an approach that Dowling (2010) uses when teaching isiXhosa to non-mother tongue speakers.

\section{STUDENTS' VIEWS ON HOW THE MODULE CAPACITATED THEM TO TEACH IN MULTILINGUAL CLASSROOMS}

\section{A need to design a module that enhances language acquisition}

Participant 13 thought that this module enabled her to 'pronounce different words and ways, and write grammatically correct sentences'. However, most of the participants during the interviews revealed that they felt their communicative abilities in isiXhosa were rather limited. Their main concern was on how the offering mode of the module was limiting their potential to acquire the 
language. Participant 7 said that 'there were many things to remember in a short space of time' and Participant 1 said that 'offering this module in the $4^{\text {th }}$ year is not enough'. These assertions challenge the purpose for which this module was designed, as most explanations to the drawings and discussions suggest that student teachers recognised a huge need for them to be able to communicate in isiXhosa in the classroom. This view is clearly expressed by Participant 5 as 'it was frustrating for me to know a few words here and there but not be able to contextualize them as support tool in the lesson'. What seemed to be the concern was not just the ability to speak but to be able to scaffold learners' thoughts and speech for effective learning. For any interaction to take place in the classroom, both teachers and learners need to be able to communicate with one another (Nomlomo, 2010).

When student teachers were in schools during the teaching practice, their challenge was with the mentor teachers who did not seem to share their views. Participant 10 said that 'my mentor teacher was not keen on me using isiXhosa to explain concepts during my teaching'. On further inquisition, the participant hypothesised that since most teachers can't speak isiXhosa they have caged themselves to the norm and therefore are not prepared to shift from their comfort zone. This is understandable given the hegemony of English (Alexander, 2000) and the paucity of school language policies that do not just recognise the multilingual nature of their schools but translate this knowledge into the curriculum (Probyn, 2009). Multilingual awareness has been criticised by some scholars as it fails to disrupt the status quo of English as a dominant language in schools (Bourne, 2001; Garcia, 2009).

As much as the student teachers recognised the positive purposes of learning isiXhosa and expressed their concerns about the module, they also suggested ways they felt could develop the module. Participant 8 strongly suggested that 'I think the most essential addition to $a$ conversational module is that of being regularly immersed in an isiXhosa speaking environment. In order for one to converse in isiXhosa, there needs to be a flowing dialogue between sender and receiver and this can only be experienced in real life situations. In the module currently scenarios are created, in which we can engage, but these are superficial as they are based on hypothetical situations which may play out very differently in real life; thus leaving us unequipped for the real world; therefore essentially contradicting the main aim of the module. In order to gain a broader understanding of such situations, and being better equipped with the language, the students need to experience these situations first hand'. This assertion highlights immersion as an approach to enable students build their conversational competencies in the target language; it also questions the lack of classroom experiences that provide a space for them to use isiXhosa. Immersion as an approach to learning a foreign language was first used in Canada with immigrant learners who were taught French (Graber \& Stoller, 1997). It was not successful in helping the learners to acquire the language, because neither their social nor their academic contexts exposed them sufficiently to the language. Moreover, English is still dominant as a preferred language of communication, despite the elevation of the status of indigenous languages (De Klerk, 2002). A total immersion experience points to contexts where students can practice their teaching in foundation phase classrooms where isiXhosa is the language of learning and teaching where students will be able to 'to experience these situations first hand'.

Participant 9 felt that 'The Xhosa conversation module needs to be from first year so that we are able to become comfortable with the language and not just momorise (sic) words and their Per Linguam 2015 31(1):1-14 
meanings for a test but instead to be able to use the language and feel comfortable using it'. This view supports Cummin's (1979) suggestions on the relationship between language and cognition. He mentioned that under ideal conditions it takes about two years for children to acquire basic interpersonal skills in the second language. However, in the case of these students, isiXhosa is a second additional language and in most cases they do not interact on a social basis with speakers of isiXhosa (Kese, 2012). This implies that it might take more than two years for them to acquire the language, but there is no empirical evidence to suggest that adult learners do not have the ability to acquire another language. If the ultimate goal of learning isiXhosa is to enable students to effect learning in their multilingual classrooms, 'memorising words and their meanings' will not assist them in acquiring the language, as most studies on second language acquisition advocate for a meaningful interaction with the language (Graber \& Stoller, 1997).

Students' voices are crucial in providing insight on effective learning. Clearly, in their view, learning isiXhosa is important and it must address the communicative needs of a multilingual classroom.

\section{CONCLUSION}

The research questions that were addressed in this study were: What do foundation phase student teachers think is the purpose of learning isiXhosa in a BEd (Foundation Phase) programme? How has this module capacitated students to effect teaching and learning in their multilingual classroom? Data suggest that students' views point to the significance of learning isiXhosa, critique the current mode of presenting the module, and highlight best practices that will enable them to improve teaching and learning in a foundation phase multilingual classroom. From these findings, two implications can be drawn. Firstly, students' views challenge the current language policies in schools which are monolingual in nature and do not take into account the communicative demands of a multilingual classroom. This view resonates with Makalela's (2013:121) assertion that multilingual speakers have an 'extended linguistic repertoire from which they extract a range of language forms in order to express meaning'. Extending this view to classrooms, it means that teachers can no longer continue with monolingual practices. Students experienced first-hand what it means to be a teacher in such contexts and were able to reflect on how isiXhosa has been positioned in the BEd (Foundation Phase) teacher programme and how they have been capacitated through the isiXhosa conversational module to teach in multilingual classrooms. These views also raise a debate on how teacher education programmes can recognise the value of indigenous languages not just to be learnt for social purposes over a one-year period but to be positioned as important languages that contribute to learning at higher education institutions.

Secondly, these data imply that modules should be designed in terms of needs as some students felt that learning isiXhosa goes beyond the classroom but should enable them to communicate in multilingual South African contexts. It is clear that there is a gap between what students currently learn in this module and what the communicative demands of using isiXhosa are in their lives. Data have revealed clearly the shortcomings of how the current isiXhosa module meets the demands of their 'real world'. The onus lies with curriculum developers in the BEd (Foundation Phase) programme to learn from the student teachers' 'voices' on the many possibilities that can equip them to 'use the language and feel comfortable in using it'. Clearly, there is a need to 
design communicative tasks where students would be afforded an opportunity to interact with isiXhosa in order to acquire the language (Visser \& Venter, 2004). There is therefore an urgent need to implement the suggestions student teachers have highlighted and to rethink ways in which an isiXhosa conversational module can have useful content that capacitates them to effect teaching and learning in multilingual contexts.

\section{REFERENCES}

ALEXANDER, N. 2000. English unassailable but unattainable: The dilemma of language policy in South African education. Praesa Occasional Papers 3. Cape Town: Praesa.

BLACK, L. 2004. Teacher-pupil talk in whole-class discussions and processes of social positioning the primary school classroom. Language and Education, 18(5):347-360.

BLOCH, C. 2002. A case study of Xhosa and English biliteracy in the foundation phase versus English as a 'medium of destruction'. Perspectives in Education, 20(1):65-78.

BLOMMAERT, J, J COLLINS \& S SLEMBROUCK. 2005. Spaces of multilingualism. Language and Communication, 25:197-216.

BOURNE, J. 2001. Doing 'what comes naturally': how the discourses and routines of teachers' practice constrain opportunities for bilingual support in UK primary schools. Language and Education, 15(4):250-268.

BRAUN, V \& V CLARKE. 2006. Using thematic analysis in psychology. Qualitative Research in Psychology, 3(2):77-101.

CRESWELL, JW. 2009. Research design: qualitative, quantitative, and mixed-methods approach (3rd edition). Thousand Oaks, CA: SAGE.

CUMMINS, J. 1979. Linguistic interdependence and the educational development of bilingual children. Review of Educational Research, 49(2):222-251.

DE KLERK, V. 2002. Language issues in our schools: whose voice counts? Part 1: the parents speak. Perspectives in Education, 20(1):1-14.

DE LANGE, N, T OLIVIER, J GELDENHUYS \& C MITCHELL. 2012. Rural children picturing life. Perspectives in Education, 30(1):79-89.

DEPARTMENT OF EDUCATION. 2011. National Qualifications Framework Act (67/2008): Policy on the Minimum Requirements for Teacher Education. Government Gazette no. 34467. Pretoria: Government Printers.

DOWLING, T. 2010. Taught language or talked language: second language teaching strategies in an isiXhosa beginner's class at the University of Cape Town. In Desai, Z, M Qorro \& B Brock-Utne (Eds), Education challenges in multilingual societies: LOITASA Phase Two research. n.p.: African Minds. 113-128.

EVANS, R \& A CLEGHORN. 2010. 'Look at the balloon blow up': student teacher-talk in linguistically diverse Foundation Phase classrooms. Southern African Linguistics and Applied Language Studies, 28(2):141-151.

GARCIA, O. 2009. Bilingual education in the 21st century: a global perspective. Chichester, UK: WileyBlackwell.

GRABER, W \& FL STOLLER. 1997. Content based instruction: research foundations. Available from http://ww.carla.umn.edu/cobaltt/modules/principles/grabe_stoller1997/Reading1/ Foundation.htm [Accessed: 3 March 2014]

KESE, P. 2012. Teaching non-indigenous speakers of isiXhosa: a critical evaluation of own practice. Per Linguam, 28(1):92-110.

KRASHEN, S. 1982. Principles and practice in second language acquisition. Oxford: Pergamon Press.

MADIBA, M. 2012. Language and academic achievement: perspectives on the potential role of indigenous African languages as lingua academia. Per Linguam, 28(2):15-27. 
NN Mayaba

MAKALELA, L. (2013). Translanguaging in kasi-taal: rethinking old language boundaries for new language planning. Stellenbosch Papers in Linguistic Plus, 42:111-125.

MAIR, M \& C KIERANS. 2007. Descriptions as data: developing techniques to elicit descriptive materials in social research. Visual Studies, 22(2): 120-136.

MAKOE, P \& C MCKINNEY.2009. Hybrid discursive practices in a South African multilingual primary classroom: a case study. English Teaching: Practice and Critique, 8(2):80-95.

MERCER, N. 1995. The guided construction of knowledge. Clevedon: Multilingual Matters.

MITCHELL, K. 2012. English is not all that matters in the education of secondary multilingual learners and their teachers. International Journal of Multicultural Education, 14(1):1-21.

NAICKER, S \& R BALFOUR. 2009. Policy and strategies for ESL pedagogy in multilingual classrooms: the classrooms talk programme. The Language Learning Journal, 37(3):339-358.

NOMLOMO, V. 2010. Classroom interaction: turn taking as a pedagogical strategy. Per Linguam, 26(2):50-66.

O'CONNOR, J \& M GEIGER. 2009. Challenges facing primary school educators of English second (or other) language learners in the Western Cape. South African Journal of Education, 29:253-269.

PIENAAR, C \& E RAYMOND (Eds). 2013. Making Inclusive Education work in classrooms. South Africa: Pearson.

PLUDDEMMAN, P, X MATI \& B MAHLALELA-TUSI. 1998. Problems and possibilities in multilingual classrooms in the Western Cape. Praesa, Cape Town.

PROBYN, M. 2009. 'Smuggling the vernacular into the classroom': conflicts and tensions in classroom codeswitching in township/rural schools in South Africa. International Journal of Bilingual Education and Bilingualism, 12(2):123-136.

PONTEFRACT, C \& F HARDMAN. 2005. The discourse of classroom interaction in Kenyan primary schools. Comparative Education, 41(1):87-106.

SETATI, M \& J ADLER. 2000. Between languages and discourses: language practices in primary multilingual mathematics classrooms in South Africa. Educational Studies in Mathematics, 43:243-269.

SOSIBO, L. 2012. Exploring the views of educators and students on privileged knowledge domains in a teacher education programme: a case study. Journal of Education, 56:139-161.

SWARTZ, C. 2011. 'Going deep' and 'Giving back': strategies for exceeding ethical expectations when researching amongst vulnerable youth. Qualitative Research, 11(1):47-68.

THERON, L, C MITCHELL, A SMITH \& J STUART (Eds). 2011. Picturing research: drawing as visual methodology. Rotterdam: Sense Publishers.

VAN DER WALT, C. 2009. The functions of code switching in English language learning classes. Per Linguam, 25(1):30-43.

VISSER, M \& E VENTER. 2004. Genre analysis and task based course design for isiXhosa second language teaching in local government contexts. Per Linguam, 20(1):36-56.

VYGOTSKY, L. 1978. Mind and society. Cambridge, MA: Harvard University Press.

\section{BIOGRAPHICAL NOTE}

Dr Nokhanyo Nomakhwezi Mayaba is currently a post-doctoral fellow at the University of South Africa. Her research interests are in the field of language education; in particular, language across the curriculum, the role of indigenous languages in facilitating learning in multilingual classrooms and the use of folktales to enhance the resilience of children in primary schools. She was part of the 2009-2010 SANPAD Research Capacity Initiative programme, is a recipient of the Education Association of South Africa doctoral award and was recognised and awarded a certificate as the Faculty of Education Emerging Researcher of the Year at NMMU in 2013.

Email:mayabnn@unisa.ac.za 